Paideusis

\title{
The Opacity of the Self, Sovereignty \& Freedom: In Conversation with Arendt, Butler \& Derrida
}

\section{Graham Giles and Cristina Delgado Vintimilla}

Volume 16, Number 2, 2007

URI: https://id.erudit.org/iderudit/1072578ar

DOI: https://doi.org/10.7202/1072578ar

See table of contents

Publisher(s)

Canadian Philosophy of Education Society

ISSN

0838-4517 (print)

1916-0348 (digital)

Explore this journal

Cite this article

Giles, G. \& Delgado Vintimilla, C. (2007). The Opacity of the Self, Sovereignty \& Freedom: In Conversation with Arendt, Butler \& Derrida. Paideusis, 16(2),

35-44. https://doi.org/10.7202/1072578ar
Article abstract

This paper asks and examines the question "who are you?" In doing so it embarks across the conceptual terrain of subjectivity, passing through five different regions. First is the subject and otherness, in which are considered Arendtian notions of the "who" of the individual in the appearing world. Next is the relation between the "I" and the "you" in systems of recognition, and how those systems are creations and expressions of social normativity. This is followed by the idea of the sovereignty of the self as a reaction to its dislocation within systems of recognition. Sovereignty as such is viewed through the thought of Jacques Derrida and Hannah Arendt. With Foucault, the authors approach the question of social normativity as a frame rather than a constraint by which the self is stylized. The fourth section of the paper then explores self-questioning as a means of explicit or intentional self-stylization. Contrasting the "mere liberation" of thinking in Arendt's thought with broader understandings of freedom, the fifth section relates Arendt's conception of the miraculous with Derrida's of the event. The paper's trajectory returns in conclusion to the implications of its course for the initial question of who one is, particularly with respect to the teaching subject. (c) Graham Giles, Cristina Delgado Vintimilla, 2007

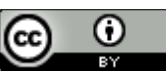

This document is protected by copyright law. Use of the services of Érudit (including reproduction) is subject to its terms and conditions, which can be viewed online.

https://apropos.erudit.org/en/users/policy-on-use/ 


\title{
The Opacity of the Self, Sovereignty \& Freedom: In Conversation with Arendt, Derrida $\mathcal{E}$ Butler
}

\author{
GRAHAM GILES \\ University of British Columbia, Canada
}

\author{
CRISTINA DELGADO VINTIMILLA \\ University of British Columbia, Canada
}

\begin{abstract}
This paper asks and examines the question "who are you?" In doing so it embarks across the conceptual terrain of subjectivity, passing through five different regions. First is the subject and otherness, in which are considered Arendtian notions of the "who" of the individual in the appearing world. Next is the relation between the "T" and the "you" in systems of recognition, and how those systems are creations and expressions of social normativity. This is followed by the idea of the sovereignty of the self as a reaction to its dislocation within systems of recognition. Sovereignty as such is viewed through the thought of Jacques Derrida and Hannah Arendt. With Foucault, the authors approach the question of social normativity as a frame rather than a constraint by which the self is stylized. The fourth section of the paper then explores self-questioning as a means of explicit or intentional self-stylization. Contrasting the "mere liberation" of thinking in Arendt's thought with broader understandings of freedom, the fifth section relates Arendt's conception of the miraculous to Derrida's conception of the event. In conclusion, the paper's trajectory returns to the implications of its course for the initial question of who one is, particularly with respect to the teaching subject.
\end{abstract}

\section{Who are You?}

Who are you? This is a question that we pose to others as an act of recognition, a willingness and acknowledgment that there is an other whom we encounter and whom we do not know. It may also be seen as a question from which, in the moment it is posed, an echo reverberates which asks of us in return "Who are you?"

When the British band The Who sang "Who are You?" they performed what could be considered a Derridian double move. Of course, first there is the question itself, forceful and demanding, now seen as emblematic of an eruptive generation's quest for a meaningful place in a turbulent and hostile world. Second and more subtly is an assertion, of the sort common in marketing and advertising, of belonging, of belonging in something which is ostensibly only inquiring. The question asserts an identity of the questioned and prescribes a disposition. "Who are you?" means that you are the 'who,' that you are us. The apparent question makes of the encounter an instance of identification and subject formation even as it asks the question it answers. Such a clear example of the way in which an address already answers itself is our point of departure in considering the self, sovereignty and freedom in this paper.

(C) Copyright 2007. The author, Graham Giles and Cristina Delgado Vintimilla, assign to Paideusis the right of first publication and educational and non-profit institutions a non-exclusive license to use this document for personal use and in courses of instruction provided that the article is used in full and this copyright statement is reproduced. Any other usage is probibited without the express permission of the authors. 
If education is to be in some measure considered an ethical project in the institution of culture, the question of who is undertaking it (as teacher or student) assumes broad significance, one too often disambiguated. 'Who one is,' for Hannah Arendt, assumes a dimension of salvation from the totalitarian forces of sameness. For Judith Butler, it is an unanswerable question that opens our thought to a different conception of responsibility. For Jacques Derrida, it might be a richly unfolding weave of meaning, one reappearing as a new echo of itself in each subsequent moment. In this paper's exploration we consider how to re-conceive the notion of our personhood in order to orient the teaching subject more meaningfully to the possibility of a rich ontological horizon in questions of ethics and meaning in her or his work. In other words, we ask what is it possible to be as a teacher and in what ways might one meaningfully consider this question. From this we are led to take up the question of freedom more generally, concluding with a reappraisal of the concept of autonomy for teachers and teaching.

\section{Otherness \& Subjectivity}

Subjectivity for Hannah Arendt is an obscure and radically individual phenomenon, one wrought up in the experiences, in the "suffering" which obtain in our appearance and action in the world. Subjectivity is to be considered in the context of its existence or more precisely, in its utterly distinct appearance, in a world shared in common with others. Outside of the "darkness" of our inner life, and the miasmic "welter of happenings" (Arendt, 1978a, p. 72) of the soul, we appear-or what Arendt (1958) calls our "who" (p. 179) appears (in contradistinction to the "what")-in the world as something distinct, singular and therefore new. Such appearance characterizes the human world most fundamentally in plurality and natality. If the newness of human distinctiveness inscribes the world with natality, the plurality of such distinctiveness does so with otherness. Thus, for Arendt, the experience of the subject is one significantly of otherness.

How is such an experience of subjectivity recognized in the teaching profession? We pose the question in part in response to our experience in teaching and teacher education, a culture which still celebrates sameness, often in the name of diversity.

Nietzsche (1994) opens On the Genealogy of Morality thus: "we are unknown to ourselves... and there is good reason for this" (p. 3). Arendt (1958) follows Nietzsche by asserting this unknowingness as a difficult necessity of action, which for her is synonymous with a beginning, "it is not the beginning of something, but of somebody, who is a beginner himself" (p. 177). At this point we may ask what it would mean for education to consider unknowingness as a necessity for action? As well, how is beginning conceived in education today? In teacher education, beginning is often construed as a lack, a lack of experience, or of knowledge, instead of being considered as a moment of newness as it could be for Arendt. For Arendt, in action, a beginning is a disclosure of a distinct self whose distinctiveness actualizes plurality. This plurality is necessary for ethics by virtue of what we could consider its gift of the unexpected or the unknown. In teaching culture, this is a gift that is customarily considered a threat. The subject as a gift or a "promise to the world" (1978a, p. 36) must suffer the frustrations of action by risking the disclosure of a self unknown to itself, and feeling alive without knowing "exactly why or in what" (1958, p. 193). The frustrations of the acting subject consist as well in the power of the action, beyond control and understanding in its inherent boundlessness and unpredictability and in the uncertainty as to its author. So, we become an existing somebody, as opposed to a behaving no one, by risking self-disclosure in uncertainty and suffering the inability to control the consequences or meaning of our actions. This disclosure requires others to whom to appear in distinctiveness. In part because we are unknown to ourselves, we appear in distinctiveness "visible only to others" (Arendt, 1958, p. 193) among whom we may actualize a reality beyond the presumptive darkness of the soul. Others in turn, in the interplay of what Arendt called the public realm, appear and manifest a plural world whose possibility is boundless. In education, the moral romance of good and empathetic subject threatens to 
eclipse the primacy of Arendt's appearing world and the subject's obscurity to itself in misrecognition of how and why we need others and a world beyond ourselves to be. Clearly however, this being is not so simple.

\section{The Other and the I}

This Other with whom I appear in the world, with whom I may share an act of recognition, is an Other whom I cannot know or apprehend, unsubstitutable and unique and yet is an Other with whom I share an ego like my own. Although the other is a wholly other, there is a symmetry in the similarity of our egos, in the structures of our consciousnesses. In this relationship between the I and the You, the central question becomes one that Arendt (1958) in the Human Condition wrote as the question we must ask and answer: "Who are you?" (p. 183). In Relating Narratives, Adriana Cavarero takes up this question to illuminate Arendt's relational politics or what Judith Butler (2005), referring to Cavarero's work, calls the "politics of 'the who" (p. 31). In Arendtian terms, this politics may be seen in how what you are may circumscribe who you can be, at least to the extent that what you are proscribes your access to any sort of appearing public.

With Butler then we may agree that the explication of the politics of the who "counters a certain ethical violence, which demands that we manifest and maintain self-identity at all times and require that others do the same" (p. 42). This we may encounter in the way the teacher is portrayed as a subject, always coherent and self-mastering in order to be professional. An invitation or call for a suspension of coherence and self-identity is complicated when the structure of address for recognition and my desire for recognition demand not only coherence and self-identity but also to be part of a conventionality and a normativity that will allow me to be recognized by the other. My appearing in the world happens already within a social-historical imaginary, structures of interpretation which Castoriadis (1991) calls the "magma of instituted significations" (p. 65). This social-historical imaginary and the norms of a determined context haunt, as Derrida would say, the horizon of possibility of being and becoming. There are structures of intelligibility "always already" that precede my encounter with the other. The act of recognition of myself, as well as of the other, is proscribed (and even effected) by certain norms, conventions and criteria that recognize and evaluate who I am. The I is not offering recognition based in her or his own autonomous terms (although we may be haunted by this illusion of self sovereignty). The I is always already subjected to a social normativity which precedes it and produces the structures of interpretation which bestow on it recognizability. Our sense and need for recognition within what Derrida called the teaching body is a strong call, one which employs the language of accountability and profession. What would it mean then, for the teaching subject to risk unrecognizability and in the name of what responsibility should such risks be undertaken?

\section{A Dislocated Self}

As there exists a prior aesthetics of recognition, a specific regime of visibility and intelligibility, a preordinary politics of the "who," the subject invariably experiences what Levinson (1997) calls a "belatedness" (p. 435) in appearing in the world as a unique and distinctive being. Levinson, considering Arendt and education, identifies this as the "paradox of natality" (p. 436) in which encounters between students and teachers are "always both familiar and new" (p. 436). Derrida (2004) elaborates something similar as an "anachrony of oneself, anachrony in oneself" (p. 113) which anticipates well what Butler describes as normative efficacy in both constraining and constituting the subject. One appears in the world as a self constituted in part by pre-existing norms, understandings which confer recognition. As such, selfhood is always dislocated, in anachronous tension between given 
structures of interpretation (which make its self intelligible to itself) and newness, the bewildering primacy of unmediated experience or some would say, the unconscious. In this sense, we are already the self from whom we desire recognition, already of the norm that answers to "who are you?" for us, already the other we do not know. Put another way, by virtue of the circumstances of its inauguration, in the $\mathrm{I}$ is already the You that is unknown. Butler (2005) cites Hegel in describing the "double significance" (p. 27) of an action which is both that of the self and that of the other, significant within the subject to both itself as conditioned and as new.

The subject as invested with an existing authority, the social normativity that inheres in the other (within and without oneself) may be recognized but never fully reconciled because "the 'I' resides in a perspective that dislocates the perspective that it conditions" (p. 28). The argument that it is ever thus, a Levinasian one, is that one is other before one is I; before one emerges as what one comes to recognize as a self, one is constituted by the other. The ethical significance of this is that, if neglected, our originary opacity constitutes a vulnerability to heteronymous normativity, a disposition of susceptibility and as Arendt warned, to simply exchange one set of habits for another without the development of a capacity to judge. Before we move to a consideration of autonomy as freedom in two different aspects, we must turn to ways the subject can become stylized in reaction to its dislocated constitution, its 'troubling' ontological multiplicity. This becomes an important matter if we consider that a teacher is already constituted by certain understandings of what a teacher is or can be and is thus recognizable as such. In striving for certain ideals of what being a teacher is, we may neglect the extent to which we are predisposed to such images and how complex and often conflicted they may be.

\section{A Recourse to Sovereignty}

Lacan writes of the ego as "inauthentic agency functioning to conceal a disturbing lack of unity" (Leader \& Groves, 1995, p. 24). Argued in different registers by both Arendt and Derrida, this is as well a Cartesian legacy, subsequently inscribed with moral authority by Christian tradition, modern technoscientific rationality and behaviorism. These can be said to have had a hand in the overlay of a unitary ontology on the multiplicitous self. In the other, in the you, the self may come to recognize and evacuate its unknown "to purge and externalize its opacity" (Butler, 2005, p. 46) in "a vain effort to destroy the structural similarity between the two and restore itself to a sovereign position" (p. 26-27). Colloquially this is to hate most in the other what one hates most in oneself, which would in this view be what threatens one's sovereignty or command, which is that which defies it: Our unknownness to ourselves. The trope of restoration is indicative of the nostalgia sovereignty generates in rejecting the inevitable frustrations of the desire for recognition by asserting the projection of a singularity-a unity - as an indivisible coincidence of the self with itself or what we call the individual. Thus, and necessarily very briefly, the modern understanding of sovereignty has portrayed the subject as a unity, as an autonomous, liberal self, in sympathy with the idea sovereignty accorded the modern nation state.

When Derrida considers sovereignty he describes the coincidence of the self with its self as one of the characteristics of what he calls the phantasm of sovereignty. He argues that what is relevant to the concept of sovereignty is not whether it can be considered in terms of truth or falsity or image or reality but rather that it be considered in terms of power. Michael Naas (2007) refers to Derrida's conception of sovereignty thus:

The phantasm is not a representation or misrepresentation of the way things are but a projection on the part of a subject or nation state of the way one would wish them to be - and thus, in some sense, the way they become, with all their real, attendant effects (p. 19).

For Derrida sovereignty is intimately related to power. It is a powerful fiction that does not project itself as a fiction—as an "as if"-but as "real", organic and truthful, and thus as "as such". 
Here we have a twofold consideration, on one hand the modern idea of sovereignty allows the teaching subject to work with the inherited presumption of the fiction of believing his or her self free from structures of interpretation which have already spoken and are already speaking to who she or he can be as a teacher. On the other hand, the modern image of the autonomous teacher is one enabled by the facility of developmental psychology which permits the management of the other and the persistence of the phantasm of sovereign mastery. In Arendt's terms, the difficulty of such governance is not that they are ultimately ineffective, but that "they work too well" (Arendt, 1958, p. 221).

Arendt locates in western traditions of thought—as "the culmination of the modern age's subjectification" (1978b, p. 177)—the conflation of freedom with the free will of a sovereign self. Derived from a Platonic view of rulership, one whose legitimacy rested upon the domination of the self, freedom and the power of the I became synonymous in the modern age. She draws upon Heidegger to note the paradoxical vacuity of this will to power, the will of the commanding self in inability to command anything other than itself "its own superior" (p. 177), to install itself sovereign. For Arendt this is a prejudice of disastrous consequences, one which, in terms of this paper would be tantamount to the abrogation of any ethical horizon whatsoever, to the dismissal of the other and a naked vulnerability to the effect and operation of heteronymous social normativity. This is the vulnerability which threatens humanity with superfluity by robbing us of the particularity of our appearance. It is the vulnerability which has invited self-annihilation on a horrendous scale. For Arendt (1968), "freedom and sovereignty are so little identical that they cannot even exist simultaneously" (p. 164) for sovereignty is a "contradiction to the very condition of plurality" (p. 234) and "can only be maintained by instruments of violence" $(1968,164)$. "Nothing can be more frightening than the notion of solipsistic freedom," she writes (1978b, p. 195) in reference to the tendency, from the feeling of standing apart, "to assert and 'I-myself' against an indefinite 'they"' (p. 195). For the subject her or himself, the sovereignty of the will affords a sense of mastery and strength at the cost of the requirement to overlook "the unpleasant, paralyzing sentiments of being coerced" (Arendt, 1978b, p. 161), to overlook how readily we come to recognize ourselves in a way which affords only that one become "one's own slave" (Arendt 1958, p. 211). To think of ourselves as coherent or individual is to coerce ourselves away from the ambiguous complexity of our appearance in this world, in a world of others. To hold such a view, oriented to causality and expectation, is to assert in sovereign mastery an ethical violence, a world of singularity, the world as one self and thus one world.

In education, such coercion is amplified and reinforced by requirements of professional competence, the necessities of security (physical and social), the dictates of classroom "management", essentializing normative discourses of personal needs, and the gaze, or imagined expectations, of fellow professionals in school communities which exist in institutional frameworks which are themselves a legacy of scientific management.

\section{The Liberation of Self-Questioning}

We have been considering how instituted structures of consciousness are enclosive for the subject. We wish to turn to the question of what opportunities flow from such awareness and how, in a different understanding, we may imagine autonomy and freedom anew. In agreement with Foucault, we consider social normativity as a framework that does not act deterministically on the subject but rather as the frame for the subject's self-crafting or self-stylization. Butler (2005) elaborates:

The norm does not produce the subject as its necessary effect, nor is the subject fully free to disregard the norm that inaugurates its reflexivity; one invariably struggles with conditions of ones own life that one could have not chosen. If there is an operation of agency or, indeed freedom in this struggle, it takes place in the context of an enabling and limiting field of constraint. (p. 19) 
So there is an aporetic condition in which the subject lives, a struggle that characterizes the act of self crafting in a world that already produces a sense of one's self, a self habituated to the habits of sovereign prejudice. Questions for us follow as to how this aporetic condition is made visible in teaching and do technologies of self-fashioning, as McWilliam (forthcoming) would say, called "professional development," consider its implications and consequences, its ethical depth and moral legacy? We contend that it is precisely the thematization, to use a Derridian term, of aporetic condition that prompts the agency of the subject and its stylization. As Butler points out: "This struggle with the unchosen conditions of one's life, a struggle — an agency — is also made possible, paradoxically, by the persistence of this primary condition of unfreedom" (p. 19). The relationship between subject and norms haunts the relation of the subject to himself because social normativity is intimately related to the ontological stylization of the subject as well as to his or her own ontological horizon of possibility. These assertions beg the question then of what ontological stylization is possible for the teacher today within current structures of normativity. Hence we could say with Butler:

...to call into question a regime of truth, where that regime of truth governs subjectivation, is to call into question the truth of myself...if I question the regime of truth I question, too, the regime through which being, and my own ontological status, is allocated (p. 23).

This would require of a teacher to be vulnerable and yet suffused with the richness of questioning. From this perspective, self-questioning is an ethical act made possible by critique. The question here becomes how self-questioning can take place in a tight system of excellence and accountability, which are already defined, and the question of what teaching is appears a settled one.

The act of self-questioning according to Butler, and echoing Arendt, requires always the courage to risk oneself when appearing to others because the subject risks being unrecognizable in questioning norms or opening questions as to who one is and who one is allowed to be with respect to an explicated determined normativity. Here we are evoking a teacher that risks unrecognizability through self-questioning and in it sees and can endure the promise of what may be possible though yet unintelligible. This may not be a teacher we recognize, one who manages risk in order to contain or solve it, but instead would be one who approaches risk as Foucault (1985) described it, as Truth itself (p. 6). This is a teacher who embraces risk as the possibility for something unexpected to happen, who lives with the uncertainty of risk, understanding it as a rich promise. Approaching risk in such a way invites again the question of a teacher risking unrecognisability - in this case in a deliberate mode of thought-because, as we shall see when we meet the event, without it there is no risk. It follows that the act of self-questioning requires an unconditional freedom of thought that, for Derrida, is given by the mode of thinking of the "perhaps". This may be considered a mode of thinking of critique which always gives the space to what is not yet here, to what is not conventional or agreed upon. The "perhaps" is outside of what "must be" to invite what "might be". Thus, Derrida argues, it is an unconditional freedom of thought that ought to challenge not just what is conventional or taken for granted but also the power and fictions of the phantasms of sovereignty.

Continuing in an Arendtian (1978b) vein, the subject is a thinking ego which "recoils upon itself musing on fundamental incomprehensibility" (p. 197). In this notion we have in concert two important themes of this paper, that of reflexivity in self-questioning and that of the unknowable or incomprehensible. To be conscious in the sense Arendt (1971/2003) derives from the etymology of the word, is to be multiple, to "know with myself" (p. 183). Thinking is a sympathetically multiple activity insomuch as it is a "soundless solitary dialogue" (p. 187), one well suited in this conception to the multiplicity of the self posited above. Loosened from the will's singularities and phantasms by selfquestioning critique, Arendt (1978b) allows a view of the thinker "not summoned by himself to his self" (p. 187), which we could take to mean not circumscribed exclusively by forms prescribed by what is given, in effect, to be able to "join itself to what is absent" (p. 194) or as Derrida would say, to what is "yet to come." 


\section{Toward Freedom}

If anywhere we would hope to find thinkers examining the impediments and incitements of their thinking, it would be in education. When considered in relation its constitution by forces of social normativity and the sovereign phantasms of recognizability, thinking aspires however in the fullness of its promise in only the "mere liberation" (Arendt, 1978b, p. 206) Arendt cautions us not to mistake-in what she calls a "decisive distinction" (p. 206)—for actual freedom. She warns of the susceptibility of "philosophical freedom" to the command of the will and was haunted in her work by the question of how great thinkers such a Heidegger could so readily become subject to totalitarian ideology. The promise of liberation of self-questioning-or thinking - is preparatory then to a more significant readiness in the form of judgment whose instantiation can only manifest among others and is thus, primarily, a political and secondarily, a philosophical concern. In this movement we necessarily observe and elaborate a shift from the freedom from (in the opening of a space of liberation in self-questioning) to the freedom to Arendt argues as the more politically significant freedom, offering two ways of understanding the concept.

Arendt (1978b) writes of the requirement to be aware of the line separating ordinary activities from our reflections on them (p. 197). This is to avoid entrapment in a world as "personified concepts" (p. 197) estranged from freedom's true ground in appearance and action. This she describes as "a realm of splendor which is not the realm of conceptual thought" (Arendt, 1968, p. 165). Freedom as "the sheer capacity to begin" (p. 169) has a propulsive "agent-revealing capacity" (1958, p. 182) of which we each individually, by virtue of the utter distinctiveness of our appearance in the world, are the first instance, a reverberation of ineffable particularity, which always appears in "startling unexpectedness" (Arendt, 1958, p. 178). She continues:

\footnotetext{
The new always happens against the overwhelming odds of statistical laws and their probability, which for all practical, everyday purposes amounts to certainty; the new therefore always appears in the guise of a miracle. The fact that man is capable of action means that the unexpected can be expected from him, that he is able to perform what is infinitely improbable (p. 178).
}

For Arendt this infinite improbability refers us to a political reality whose purpose is to expect the unexpected as the meaning of our being together. Although it is what she calls "the hidden source of production of all great and beautiful things" (Arendt, 1968, p. 169) it is "bought at the price of contingency" (Arendt, 1978b, p. 196), a contingency we learn to acknowledge in self-questioning but must live in the appearance of action and speech among others, beyond the command of our knowledge, though aware of our selves as its effect. Arendt writes of the faculty of forgiveness as necessary to the dignity of a human life of action. In a sense to act and participate in the actualization of a "miraculous" reality among others, we must forgive each other for our incapacity to overcome the aporia of our institution as subjects, wherein we wrestle with the forms that determine our engagements. It is less the outcome of that struggle than the particularity with which it is exposed to others that comprises our promise to the world and which conditions our readiness to recognize in judgment the particular and the unexpected, in other words, to welcome what Derrida calls the event.

\section{The Event}

For Derrida an event can be worthy of being considered as such only when it goes beyond the realm of what is necessary or masterable. He writes: "what takes place does not have to announce itself as possible or necessary; if it did, its irruption as event would in advanced be neutralized" (Derrida, 2002, p. 235). The event belongs to the realm and the logic of the promise, thus it never presents itself as 
something to be sure of or as a complete possibility, but rather as a may be. This may be is outside what is conventional or normatively determined and invites, as well as is open to, what is unpredictable. This unpredictability calls for a recognition of our vulnerability before what we do not control, before what is uncertain; the event is always inviting us to learn how to live with uncertainty as the open possibility to what we thought impossible. The event for Derrida cannot be predictable; he considers it an absolute otherness that we cannot forsee. Consequently the event always falls on us as a surprise. Derrida writes that:

A predicted event is not an event. The event falls on me because I don't see it coming. Like the arrivant, the event is something that vertically befalls me when I didn't see it coming. The event can only seem to me to be impossible before it occurs [arriver]" (Derrida, 2003, p. 451).

In educational terms, regimes of accountability and predictability generally leave little room for the eventual, though it may manifest in the mysterious habitus of certain teachers as an apparently personal disposition. This would be the non-technicized professional, one who could be held accountable only to a modest extent to anything one could count as measurable. Einstein kept a reminder of this with a sign on his office wall at Princeton: "Not everything that can be counted counts, and not everything that counts can be counted." (Einstein, 2007) Certainly he may be seen to be evoking the necessity for space for the eventual, one surely more scarce in what Valéry (as cited in Zaretsky, 2004) called the "delirious professions" (p. 23)—teaching, law or writing-in which one's principal resource is the opinions others have of one and all this entails in terms of the conventions of recognition. For Derrida (2002), the event is always outside the realm of the conventional.

Derrida's event and Arendt's miraculous give us ways to tentatively consider what can only be indicated metaphorically. They offer us an indication of the meaning of freedom as freedom to, for making beginnings with and among others while in the simultaneous quest for the self-reflexive liberation of thinking about our socio-historical institution. Arendt (1968) observes that "it is even a counsel of realism to look for the unforeseeable and unpredictable" (p. 170). We contend that Derrida, in the indication of the event, offers a useful parallax with which to view natality, the first fundamental characteristic in Arendt's view of the human condition. In this paper we have also explored the second characteristic of that condition in plurality, particularly as regards the constitution and self-questioning of the subject. By bringing some of the thought of these thinkers together as such, we can begin to see the outlines of a landscape of meaning and ethics responsive to both the complexities of human subjectivity and the requirements of the conditions of freedom. Perhaps we thus may begin to see with Foucault (1984) that "we are always in the position of beginning again" (p. 47) and it is this that we may need to consider if we are to "seek to give new impetus, as far and wide as possible, to the undefined work of freedom" (p. 46).

\section{To the Evanescent and the Obscure: Wither Autonomy?}

Arendt writes that she is guarded about being too at home in the world, lest she betray its eruptive heterogeneity, its natality, in the numbing automaticity of various "worldless" enclosures of meaning. She cautions to not be too pleased with freedom, as it is ever slipping away. With this in mind, as we ask how to bring together the journey of this paper's argument, we can attempt a summary. The autonomous subject is one who, obscure to her of his self, appears in evanescent "islands of freedom," ill defined and eventual. Not a reassuring prescription, to be sure. No consolation for the frailty of human life, yet, as Arendt spent most of her writing life elucidating, infinitely preferable to the tragic reiterations of attempts to overcome it. To finish with Arendt, we are "doomed to be free" and the question which remains to us is if we can bear its contingency. We are asked if we can face our deepest fear which, as Nelson Mandela has asserted, is not that we are inadequate but that we are powerful 
beyond measure. The question of autonomy then requires us to ask if we can suffer a life of action for moments of "enlarged mentality" (Arendt, 1978c, p. 257), visitors in a world full of the promise of the event, yet one we can never fully know.

So who are you? As we have traveled the terrain of this paper within view of the question, we have come to view it anew as ethically primary, but only to the extent to which we know it is one that can never be completely answered.

\section{Acknowledgments}

This paper was first presented at the 2007 Canadian Society for the Study of Education Conference in Saskatoon, Saskatchewan. The authors are particularly grateful for the support of Dr. Anne Phelan of the Faculty of Education, University of British Columbia.

The support for Graham Giles \& Cristina Delgado Vintimilla from a project reconsidering professional autonomy (supported by the Social Science and Research Council of Canada - Dr. Anne Phelan (UBC) \& Dr. Alice Pitt (York University) - principal researchers) is gratefully acknowledged.

The support for Graham Giles by the Social Science and Research Council of Canada in the form of a Canada Graduate Scholarship (2007-2008) is gratefully acknowledged.

\section{References}

Arendt, H. (1968). Between past and future. New York: Penguin Books.

Arendt, H. (1958). The buman condition. Chicago: University of Chicago Press.

Arendt, H. (1978a \& b). The life of the mind: One/Thinking(a); Two/Willing(b). New York: Harcourt Brace.

Arendt, H. (1978c). Excerpts from lectures on Kant's political philosophy. In H. Arendt, The life of the mind: One/Thinking; Two/Willing (pp. 255-272). New York: Harcourt Brace.

Arendt, H. (2003). Thinking and moral considerations. In J. Kohn (ed.), Responsibility and judgment (pp. 159-189). New York: Schocken. (Original published 1971)

Butler, J. (2005). Giving and account of oneself. New York: Fordham University Press.

Castoriadis, C. (1991). Individual, society, rationality, history. In C. Castoriadis, Philosophy, politics, autonomy: Essays in political philosophy (pp. 47-80). New York: Oxford University Press.

Cavarerro, A. (2000). Relating narratives: Storytelling and selfhood (Paul Kottman, Trans.). New York: Routledge.

Derrida, J. (2002). Where a teaching body begins and how it ends. In W. Hamacher \& D. E. Wellbery (eds), Who's afraid of philosophy? Right to philosophy 1 (Jan Plug, Trans.; pp. 67-98). Stanford: Stanford University Press.

Derrida, J. (2003). A certain impossible possibility of saying the event (G. Walker, Trans.). Journal of Critical Inquiry, 33, 441-461.

Derrida, J. (2004). Mochlos, or The conflict of the faculties. In W. Hamacher \& D.E. Wellbery (eds), Who's afraid of philosophy? Right to philosophy 2 (Jan Plug, Trans.; pp. 83-112). Stanford: Stanford University Press.

Einstein, A. (2007). Retrieved June 15, 2007, from http://www.quotationspage.com/quote/ 26950.html.

Foucault, M. (1984). What is enlightenment? In P. Rabinow (ed.), The Foucault reader (pp. 32-50). New York: Pantheon Books.

Foucault, M. (1985). The use of pleasure: The history of sexuality, Vol. 2 (Robert Hurley, Trans.). London: Penguin.

Leader, D., \& Groves, J. (1995). Introducing Lacan. Lanham: Totem Books. 
Levinson, N. (1997). Teaching in the midst of belatedness: The paradox of natality in Hannah Arendt's educational thought. Educational Theory, 47(4), 435-451.

McWilliam, E. (forthcoming). Making excellent teachers.

Naas, M. (2007). Comme si, comme ca: Fictions of self, state and sovereign god. Mosaic: A Journal for the Interdisciplinary Study of Literature, 40(2), 1-26.

Nietzsche, F. (1994). On the genealogy of morality. New York: Cambridge University Press.

Zaretsky, E. (2004). Secrets of the soul: Social and cultural history of psychoanalysis. New York: Knopf.

\section{About the Authors}

Graham Giles and Cristina Delgado Vintimilla are graduate students at the Centre for Cross Faculty Inquiry in the Faculty of Education at the University of British Columbia. They may be reached at grahamgiles@shaw.ca and crisdelgadovint@yahoo.com, respectively. 